\title{
The legacy of medicalising 'homosexuality': A discussion on the historical effects of non-heterosexual diagnostic classifications
}

\author{
Joel Anderson (Joel.Anderson@unige.ch) \\ Unité de Psychologie Sociale \\ Université de Genève, 1211 Genève, Switzerland \\ Elise Holland (Elise.Holland@unimelb.edu.au) \\ Melbourne School of Psychological Sciences \\ The University of Melbourne, Parkville, VIC 3010, Australia
}

\begin{abstract}
The classification of non-heterosexuality has changed considerably over the past century. Once considered as medical conditions attracting legal complications and serious social stigma, expressions of non-heterosexuality are now broadly considered to be normal variations of human sexuality. The historical inclusion of homosexuality in the psychiatric literature may still have implications for how sexual orientation is viewed today, including the ongoing treatment of homosexuality as an illness despite its delisting from medical diagnostic nomenclatures. This discussion paper explores the historically recorded diagnostic classification of homosexuality, reviews the processes that led to the reclassification in the nomenclature and closes with a commentary for current implications of this medical legacy.
\end{abstract}

Keywords: Homosexuality; gay men; lesbian; DSM; sexual orientation disorder; realignment therapy; conversion therapy, SOCE.

"The only unnatural sex act is that which you cannot perform." - Alfred Kinsey

\section{Introduction}

Sexuality appears to be celebrated in many of today's societies. In just a few decades, homosexuality has gone from being taboo, associated with an 'underground' existence, to becoming publicly visible and freely expressed in many Western cultures. This is evidenced by changing social norms (Pew Research Centre, 2014), popular culture, and in some instances even being associated with a certain level of cachet. For example, gay and lesbian pride events (e.g., Mardi Gras) have become annual events on many tourism calendars, popular musicians have included 'gay kisses' in their music videos, and most popular television shows feature at least one gay character.
Those of us living in certain urban cities will even be exposed to the occasional public display of same-sex affection. It appears that both popular and scientific ideas of sexuality and sexual orientation have rapidly evolved in a relatively short amount of time. Although some cultures have arguably become tolerant of gay men and lesbian women (Baunach, 2011; Loftus, 2001), there is still evidence to suggest that not all individuals (or cultural groups) concur with this attitudinal shift. Furthermore, there is also evidence that institutionalised heteronormativity (i.e., the assumption that heterosexual is the default sexual orientation) is socially and psychologically functional for heterosexual members of society (for a full review, see Herek \& McLemore, 2013). ${ }^{1}$

The psychiatric and psychological nomenclatures (Diagnostic and Statistical Manual of Mental Disorders [DSM]) have historically classified a homosexual orientation ${ }^{2}$ as a 'sexual deviation' and as a classifiable mental illness. The very fact that being gay was medically diagnosable afforded the general community a scientific sanction to treat gay men and lesbian women differentially to their heterosexual counterparts. Examples of this treatment include firing homosexual individuals from their jobs (upon disclosure of their sexuality), denying them security clearances, expelling them from their family and social groups, and turning down their United States citizenship applications (Adam, 1987). Also, gay men and lesbian women were

\footnotetext{
${ }^{1}$ Although the term 'non-heterosexuality' encompasses intersex and transsexual individuals, we will limit the scope of this paper to a focus on gay men and lesbian women. We would like to acknowledge, however, that issues surrounding medicalized discrimination towards these targets are differentially complex, and a future investigation into the legacy of the medicalization of these populations is warranted.

${ }^{2}$ We recognise the suggestion of the APA publishing guidelines that the term gay and lesbian is preferred to the term homosexual, however, when used in the context of a historical discourse it is appropriate to use the latter term. Please note that when we refer to homosexuals, we are referring to a collective of same-sex attracted individuals (regardless of their gender).
} 
prevented from practicing psychiatry, under the premise that someone who manifests psychopathology is not an ideal candidate for being a medical practitioner (Drescher, 2008). More specifically, up until the 1970s, psychiatrists who disclosed a homosexual orientation were not only at risk of losing their job, but in some parts of the US this would result in their medical license being revoked (Drescher, 2008). The original nomenclature in the early 1950 s clinically stigmatised homosexuality, indisputably classifying it as a mental illness (American Psychiatric Association [APA], 1952, pp. 38-39). The controversy regarding whether being gay should be regarded as a pathological sexual development or as a normal variant of human sexuality was debated in academic circles and in the popular press (e.g., Bell, Weinberg, \& Hammersmith, 1981; Bullough, 1976; Ford \& Beach, 1951; Hooker, 1969; Kinsey, Pomeroy, \& Martin, 1948; Kinsey, Pomeroy, Martin, \& Gebhard, 1953; Socarides, 1978a; Spector, 1977). A combination of changing attitudes and social pressures led to a 'deletion' (we will argue that this was a reclassification) of how homosexuality was defined in the DSM in 1973. This elaboration from 81 to 237 words (APA, 1968) was considered by some as a progressive step that liberated this sexual minority (e.g., John Fryer, John Spiegel; see Spiegel, 2007) . Simultaneously, the main opposing school of thought posited that it was a threat to the basic family unit, and undermined the scientific authority of psychiatry (e.g., Irving Bieber, Charles Socarides; see Spitzer 1973, 1974) .

A substantial body of literature has emerged that supports hypotheses of non-heterosexuality being compatible with normal mental health and social adjustment (e.g., Barnes \& Meyer, 2012; Bostwick, Boyd, Hughes, West, \& McCabe, 2014; Herek, 2010b; Herek \& McLemore, 2013; Hooker, 1958; Kinsey et al., 1948; Kinsey et al., 1953; Marshal et al., 2008; Oberstone \& Sukoneck, 1976; Siegelman, 1972, for a review, see Karejeski, 1996). However, experiences of discrimination have been empirically linked to the gay male and lesbian population having a greater prevalence of mental health and substance misuse problems (Feinstein, Goldfried, \& Davila, 2012). Thus, we argue for the existence of a diagnostic-cycle; although professional psychology bodies clearly state otherwise (e.g., American Counselling Association [ACA], 2006; APA 2000a, 2007; Australian Psychological Society [APS], 2007), a higher prevalence of mental health problems provides fuel to anecdotal notions that being gay may be a mental disorder. This contributes to stigma and anti-gay attitudes, which generates stressors for gay people, which in turn leads to clinical diagnoses. The current literature suggests that gay men and lesbian women are as psychologically-adjusted as their heterosexual counterparts (Rothblum \& Factor, 2001); this population as a whole, however, has a higher risk of depression, anxiety, and related problems, when compared to an exclusively heterosexual population (Cochran, Mays, Alegria, Ortega, \& Takeuchi, 2007; Feinstein et al., 2012).

Furthermore, recent research shows that the higher prevalence of such conditions can be causally attributed to the experiences of discrimination (Meyer, 2003; Thoits, 2013). It is worth noting that there is still some lingering debate about whether homosexuality is a pathological condition or a normal sexual variant (Drescher \& Zucker, 2013; Nicolosi et al., 2009; Nicolosi, Byrd, \& Potts, 2000; Nicolosi \& Nicolosi, 2002). Although those who argue the former are a numerical minority, and most have had their registration revoked from their relevant psychological communities, the fact that any doubt remains indicates to the wider public that there is an unresolved consensus within the medical community.

This article will discuss how the discourse on sexual orientation has evolved over time. We will start with a review of how non-heterosexuality has been viewed medically, by providing an extensive review of the changes in the DSM over time and examining what medical classifications have existed in print. We will then collate the various personal communications, relevant articles, and interviews that have been conducted with key players in this debate to provide a parsimonious story of how decisions were made about these classifications. We will then critically question the medical legacy that has been bequeathed to gay men and lesbian women, based on the historical treatment of sexual orientation by the medical profession(s). Finally, we discuss intervention techniques that have been (and continue to be) applied to 're-align' gay people with the 'default' heterosexual orientation (e.g., conversion and sexual re-alignment therapies, sexual orientation change efforts [SOCE], etc.), before closing with a challenge to the psychiatric disciplines. Examining the histories of this topic from a multidisciplinary perspective allows greater overall understanding to be developed as to how the values and knowledge from the past influence concepts and attitudes today.

\section{Homosexual orientation and the DSM}

The Diagnostic and Statistical Manual of Mental Disorders (DSM) originated as a method for collecting statistics concerning public mental health after psychiatry began to move towards empirical, evidence-based diagnoses. Although conceived and published in the United States of America, it is now commonly used throughout the Western world by mental health practitioners as the standard manual for the classification of mental 
disorders. Before the DSM was established in 1952, homosexuality was first classified under the category of 'psychopathic personality' in the Standard classified nomenclature of disease (1935, in Stengel, 1959). Specifically, homosexuality was classified as a 'pathological sexuality' (p. 608), which refers to sexual disturbances that require diagnosis, treatment, and prevention.

Contemporary sexual pathologies include impotence, infertility, and sexual perversions. Interestingly, there is a marked absence across all nomenclatures in differences as a function of gender; despite current understandings of the different experiences of gay men and lesbian women, they have been historically treated as a single social category.

\section{Published Nomenclature(s)}

\section{DSM-I (APA, 1952).}

In the first edition of the DSM, homosexuality was classified under the diagnostic category of 'sexual deviation', within the sub-category of 'sociopathic personality disturbances'. The diagnosis specified the type of pathologic behaviour, such as homosexuality, transvestism, paedophilia, fetishism, and sexual sadism (including rape, sexual assault, and sexual mutilation). Although referring to sexual orientation as a sociopathic personality could be considered offensive by contemporary standards, Mendelson (2003) suggests this classification was a progressive step. Placing homosexuality into this category allowed the diagnosis of deviant sexuality to be separated from more severe syndromes, such as schizophrenia and obsessional reactions.

\section{DSM-II (APA, 1968).}

Although the second edition of the DSM continued to classify homosexuality under the subdiagnostic category of 'sexual deviation', it was included within the subdivision dealing with 'personality disorders and certain other nonpsychotic mental disorders'. This category included any individual who had any sexual interest other than opposite-sex coitus. This is problematic as this classification placed being gay in the same classification as people who copulate with animals, children, and dead persons. The justification for this classification is that, although many gay individuals found their own sexual practices to be distasteful, they were unable to substitute them for 'normal sexual behaviour' (Socarides, 1978a). There was also a note in the DSM-II that this diagnosis is not applicable for individuals who only perform deviant sexual acts because 'normal' sexual objects are not available to them (e.g., incarcerated males; 1968, p.44). Issues exist here regarding the motivation behind homosexuality; there is clearly room for situational homosexuality that would not draw a clinical diagnosis. Consider the prisoner who committed same-sex rape: he would avoid the clinical diagnosis because the 'normal' sexual object of a female partner was not available. ${ }^{3}$ Conversely, the long-term gay couple in a functioning relationship would be classified as having a non-psychotic mental disorder (DSM-II code 302.0; American Psychiatric Association, 1968, p. 44).

Reprints of DSM-II from 1974 onwards no longer listed homosexuality as a category of disorder explicitly (discussed in the next section). The new classification was 'sexual orientation disturbance [homosexuality]'. One of the six revisions of the DSM-II involved an important advance with the removal of 'sexual deviations' from the general heading of Sociopathic Personality Disturbance. Even if only by name, this removed connotations of antisocial behaviour from being associated with homosexuality.

\section{The de-classification}

In 1973, homosexuality was 'deleted' from the DSM-II classification of mental disorders.

However, it was replaced by the category Sexual Orientation Disturbance; a diagnosis for gay men and lesbian women who were dissatisfied with their sexuality. ${ }^{4}$ While compiling the communications around this deletion, it becomes apparent that this was not a progressive step forward so much as a compromise between differing schools of psychiatric thought; essentially homosexuality is either a mental disorder (e.g., Irving Bieber, Charles Socarides; see Spitzer, 1973, 1974) or a normal sexual variant (for a discussion, see Stoller et al., 1973).

Prior to the official declassification of homosexuality, Spitzer was heavily involved in the re-designing of the DSM structure, in terms of classifying mental disorders within discrete

3 In accordance with the literature on contemporary rape analysis, we highlight that sexuality and rape are non-related; research shows the major motivator for rape is power (MacCannell \& MacCannell, 1993; Scully, 2013).

${ }^{4}$ The Minutes from the APA Council suggested inclusion of "Heterosexual Orientation Disturbance" (APA, 1973). However, this suggestion of diagnosing people who were disturbed with the knowledge that they are heterosexual was met with 'ridicule' that led to heterosexuality as a disorder being deleted (Socarides, 1973). Also noteworthy is the reaction of one leading gay activist at the time, Frank Kameny. He showed no objection to the modification of how homosexuality was classified. He was under the impression that any homosexual who was distressed at being homosexual was clearly 'crazy' and in need of intervention to get rid of the societally-induced internalised anti-gay attitudes (in Spitzer, 1981). 
categories, and implementing specified diagnostic criteria (Spitzer, 2008). According to Spitzer's new definition, a condition can only be a mental disorder if it causes distress or disability. Spitzer's position came to be adopted by the APA, as is evident by the inclusion of 'Sexual Orientation Disorder' in the nomenclature. Cooper (2004) suggests that Spitzer formulated a definition of mental disorder that he claimed was satisfied by all the conditions in the DSM-II (including homosexuality). She suggests that he did this as a way of defending his homophobic stance without drawing criticism for its continued inclusion in the manual. Richard Green (personal communication, 1977; in Bayer \& Spitzer, 1982) viewed Spitzer's insistence on including distressed homosexuals in the nomenclature as a poorly disguised effort to reintroduce the 'homophobic bias' of psychiatry into the new DSM, and made a very public resignation from the APA nomenclature committee over this.

\section{DSM-III (1980).}

The new category of 'sexual orientation disturbance [homosexuality]' was replaced with 'ego-dystonic homosexuality'. With this new classification, homosexuality was classified on Axis I, in the diagnostic class of 'Psychosexual Disorders'.

During the preparation of DSM-III (1980) there was important, although non-public, debate among American psychiatrists (Spitzer, 1981). From 1977, 'sexual orientation disorder' was no longer listed in the DSM-II. Before the eventual classification was decided upon for the DSM-III, there was a new interim classification of 'homodysphilia', that was quickly changed to 'dyshomophilia' (Socarides, 1978a; N.B., the medical prefix [dys] is commonly used to signify a disturbance in normal functioning). This medical prefix (i.e., 'dys') is commonly used to signify a disturbance in normal functioning; none of the other philias in the DSM at this time contained this prefix. Thus, the term 'dyshomophilia' was particularly extreme, sanctioning homosexuality as an atypical type of sexual attraction that signified a disturbance in normal functioning. According to Bayer (1987) it was also suggested that a new diagnostic category of 'heterodysphilia' be introduced for 'heterosexuals ... distressed by their sexual orientation'.

'Homosexual conflict disorder' also briefly entered the nomenclature, but eventually a classification was decided upon for DSM-III; 'ego-dystonic homosexuality' (American Psychiatric Association, 1980; Spitzer, 1981; Suppe, 1984).

The inclusion of this diagnosis in the DSM-III represented a compromise between the various clinicians and scientists who had argued in favour of delisting homosexuality from the DSM-II, and the conservative school of psychiatric thought
(Bayer, 1987; Bayer \& Spitzer, 1982; Spitzer, 1981). Opponents of this classification (e.g., individuals such as Green, Pillard, and Marmor) viewed Spitzer's insistence on including a special category for distressed homosexuals as a poorly disguised reintroduction of homosexuality into the new nomenclature. This compromise did not put the argument to rest. Arguments were fuelled by speculation that this classification still seemed founded in latent anti-gay attitudes, and since the psychological problems related to ego-dystonic homosexuality could be treated within other general diagnostic categories, it was argued to be a redundant classification that allowed for a continued irrational prejudice. ${ }^{5}$

\section{DSM-III-R (1987).}

The classification of 'ego-dystonic homosexuality' was removed in the revision of the DSM's third edition. However, professionals wishing to do so could still classify homosexuality under "sexual disorder not otherwise specified". This classification can occur with manifestations including 'persistent and marked distress about one's sexual orientation' (APA, 1987).

Ego-dystonic homosexuality was delisted from the DSM-III-R in 1987 because it was argued that "empirical data [did] not support the diagnosis, that it [was] inappropriate to label culturally induced (i.e., internalised) homophobia as a mental disorder, that the diagnosis was rarely used clinically, and that few articles in the scientific literature [used] the concept" (Krajeski, 1996, p.26).

DSM-IV (APA, 1994) and DM-IV-TR (APA, 2000).

Although no ostensible classification was available, clinicians had room to make a diagnosis of 'sexual disorder not otherwise specified' for people who have symptomology revolving around distress about his or her sexual orientation.

\section{DSM-V (2013).}

In the $5^{\text {th }}$ and current edition of the DSM, there still remains the unchanged potential for sexual orientation to be classified under 'Other Specified Sexual Dysfunction'. This classification is so broadly defined that its application would be applicable to non-heterosexuals who experience

\footnotetext{
${ }^{5}$ Arguably, while any stigma associated with nonheterosexuality exists, there will be a 'coming out' phase, or an initial phase in which individuals reveal their homosexual orientation, which could be considered egodystonic; a parallel argument to this would be that vegetarians aren't mentally ill because of their vegetarian orientation to life; the only vegetarians who need help with their vegetarianism are the ones who eat meat.
} 
distress about their sexual desires or actions. It is worth noting that the APA Task Force on Appropriate Therapeutic Responses to Sexual Orientation (APA, 2000a) do not support such classification, instead encouraging mental health professionals to promote affirmative (Bartoli \& Gillem, 2008; Crisp, 2005) and client-centred therapeutic approaches (e.g., Glassgold, 2008; Haldeman, 2004).

Although the focus of this paper has been the APA's DSM, it is worth briefly mentioning the International Classification of Disorders (ICD). Produced by the World Health Organization, ICD-9 (1977) also originally listed homosexuality as a mental illness and continued to do so until 1990 , with the publication of the ICD-10. At this point, there is still a diagnosis (F66.1) that covers when an individual's sexual orientation is clear, yet the 'patient' has another behavioural or psychological disorder which makes that patient want to change it. The diagnostic manual notes that a sexual orientation is not a disorder in itself.

\section{The Backstory to the De-Classification}

The deletion of homosexuality from the nomenclature of psychiatric disorders in 1973 was not a result of the empirically derived notion that homosexuality in itself was not a pathological orientation. We argue that this de-classification was actually no more than a re-classification. Although the 'deleted' classification could still be diagnosed (i.e., through 'Sexual Orientation Disturbance') there were many unhappy parties involved; the progay half of the argument were unhappy that the classification was not deleted in its entirety, and the conservative half were unhappy that it was changed at all. Perhaps as a reflection of the patriarchal nature of the psychiatric profession, the momentum behind the de-classification was largely driven by gay males. As such, there is a noticeable absence of lesbian women in the dialogue that is presented in subsequent sections. The extensive correspondence between the key players revolving around this controversy is evidence of an unresolved conflict over homosexuality within American psychiatry.

\section{The 'Re-Classification'}

The official story is that in December 1973, the Board of Trustees of the American Psychiatric Association (APA) voted to remove homosexuality from the DSM, and that this decision was sanctioned through a referendum in which $58 \%$ of members of the APA approved of removal of this classification (Mendelson, 2003). It is often assumed the deletion arose as a result of careful deliberation based on new-found knowledge that was derived empirically. Actually, the deletion of homosexuality from the DSM resulted from a lengthy and very public debate that climaxed in a socio-political struggle regarding what were deemed to be the rights of homosexuals (Bieber, 1987), involving violent protests, secret meetings, symposiums and referendums.

\section{Protests}

The catalyst for the protests started in the early 1960s when the psychiatric status of homosexuality became topical, and the debate was publically dominated for that decade by two New York psychoanalysts: Irving Bieber and Charles Socarides. Bieber (1965) collected data on over 100 gay men on sexual behaviour from 77 doctors, and concluded that the cause of homosexuality was a combination of over-protective mothers and detached rejecting fathers. This work is still the basis of Sexual Orientation Change Efforts (SOCEs) and reparative therapies today (an empirical critique of reparative therapy is found later in this article). Bieber's study was used as proof that homosexuality was pathological; however, strangely absent from Bieber's literature review are the findings of Hooker's (1957) seminal research published only eight years beforehand. This research revealed that homosexual populations and heterosexual populations do not differ significantly in their psychological adjustment. In 1970, the New York County District Branch of the APA appointed Socarides, a renowned psychoanalyst who devoted much of his career to understanding homosexuality, which he believed could be altered with therapy, as chairman of the Task Force on Homosexuality. The task force unanimously reported in 1972 that homosexuality represented a 'disordered sexual development not within the range of normal sexual behaviour', and that it arises 'experientially from a faulty family constellation' (Socarides, 1973). ${ }^{6}$

It was the combination of Bieber s' study, and the report from the Task Force that attracted the attention of the psychiatric world. Protests followed in response to these two events; these protests drew the attention of gay activists and led to historychanging protests at several of the annual APA conferences. Gay activists disruptively demonstrated at the annual APA conventions from $1969-1973$. This included violent and vocal protests, with both Socarides and Bieber being personally targeted (Spector 1977). In an interview with Bieber's wife (Spiegel, 2007) she said both

\footnotetext{
${ }^{6}$ Interestingly, in 1992, Socarides was a founding member of the National Association of Reparative Therapy for Homosexuals (NARTH, which was publically disavowed by the APA). It is also interesting to be aware that Socarides publicly maintained his views that homsoexuality was a 'neurotic adaption' until his death in 2005 (Fox, 2005), despite his son's prominent role as Senior White House Advisor for Public Liaison for gay and lesbian issues for the Clinton presidency (Crea, 2004).
} 
were shocked and saddened by the protests, as they felt they were genuinely helping gay men and lesbian women navigate their maladjusted natures.

The most successful protest was at the 1972 APA convention with an address to the convention by Dr. John Fryer. Fryer was previously a resident in psychiatry at the University of Pennsylvania who was fired from his position because his boss suspected he was gay. Rumours of his sexual preference followed him and he was unable to find gainful employment. After being approached by activists, he appeared (uninvited and unannounced) at the convention in cognition. Staging himself as Dr. Anonymous, in an oversized tuxedo and a rubber mask of Nixon, Fryer took control of the stage and stated, "I am a homosexual. I am a psychiatrist", and went on to inform the convention of the issues involved with declaring all homosexuals as mentally ill (Lenzer, 2003). This gave the protesters a new wave of energy, and sparked an understanding in the profession that closet homosexuals must be practicing. The protests became more vocal and violent until the declaration that homosexuality "by itself does not necessarily constitute a psychiatric disorder" was made (Spector, 1977).

\section{Closed meetings}

Coincidently, at the same time as these protests were externally pressuring the psychiatric profession, internal events were also making waves. According to an article in the New York Times (Rensenberger, 1973) an underground group which was jokingly entitled the GayPA (comprising of men like Fryer, who had made it through medical school without the disclosure or detection of their sexual orientation) allegedly met with the Nomenclature Committee of the APA in a closed meeting. They requested the deletion of 'homosexuality' from the DSM at the start of 1973. The article suggests that the group constituted several leaders of the APA, other psychiatrists, and members of the Gay Activists Alliance. John Spiegel, APA president-elect at the time (who was later revealed as a closet homosexual; Spiegel, 2007) was heavily involved in organising these closed meetings. A few months later the APA committee on Nomenclature and Statistics was seriously considering the removal of homosexuality from DSM-II; however, Socarides (1978a) claims that deletion was being considered without appropriate consultation of those who had worked in this area of clinical research (i.e., Bieber and himself).

\section{The symposium}

The combination of external political pressure from activists and internal pressures from the members of the GayPA, led to the holding of a Symposium in May 1973. It was at this symposium, entitled "Should Homosexuality be in the APA nomenclature?", that the debate reached its public peak. The nomenclature committee claimed that homosexuality held no clinical symptoms, no course of development, and no effective treatment. This was in direct opposition to the task force on homosexuality's position on this issue, as well as the general psychiatric understanding at the time (Stoller et al., 1973). The symposium is reported as finishing with a presentation by Ron Gold entitled "Stop it - you're making me sick" in which he claimed the diagnosis of illness for homosexuality is the greatest tool of oppression imaginable (in Socarides, 1973).

Following the symposium, homosexuality was deleted from the DSM, upon approval from the Board of Trustees of the APA in December 1973. The Psychiatric News claimed that the Board of Trustees essentially made its decision based on an official position paper by the Chairman of the Nomenclature Task Force on Homosexuality, Robert Spitzer (see Spitzer, 1974). The presentation of this paper asserted that homosexuality did not meet the requirements of a psychiatric disorder; it repeated Kinsey's earlier suggestion that homosexuality does not cause regular subjective distress, nor is it associated with impairing social functioning (as cited in Drescher, 2003). This statement implied that homosexuality was a normal variation of sexuality, which in turn allowed sexual orientation disturbance to be substituted for homosexuality. ${ }^{7}$

Socarides argues that this deletion of 'homosexuality' occurred without presenting 'substantive evidence for such a drastic revision of basic concepts of healthy vs. unhealthy sexual development' (Socarides, 1978b). In support of his argument, he stated that the WHO had not changed their stance on the classification of homosexuality. It is noteworthy to mention that to this day the WHO still remain ambivalent about homosexuality stating that 'it may or may not be a disorder' (ICD$10 ; 1990)$.

\footnotetext{
${ }^{7}$ In a polarised change of opinion, Spitzer presented a paper in 2001 claiming that successful change of orientation was achievable in highly motivated individuals. Although it was criticised by the APA in an official statement for its sampling method and the criteria for 'success', the study was peer reviewed and published two years later (Spitzer, 2003 . Criticisms include classifying bisexuals as homosexuals (who obviously are going to be more capable of heterosexual functioning) and using large samples of participants who had leadership roles in transformational religious institutions (Robinson, 2010). Spitzer recently repudiated these findings (Spitzer, 2012, see also Armelli, Moose, Paulk, $\&$ Phelan, 2012).
} 


\section{The referendum}

Following the official deletion of homosexuality from the nomenclature, Bieber and Socarides formed an ad hoc committee for APA members who did not agree with the declassification. Based on their research, they argued that homosexuality was not a normal variation of behaviour and therefore warranted a place in the diagnostic nomenclature. Under the pretence of advocacy, they suggested that deletion of the descriptor terms jeopardised the treatment of children who were identified as 'being at risk for becoming homosexual' (Bieber, 1987, p. 431). They suggested that the task force was not competent to handle this matter, as they lacked experience and research in the area of homosexuality.

This committee accused the leadership of the APA of giving way to political pressures, and, as a result, in 1974 the board called for a referendum amongst all members of the APA (Bayer \& Spitzer, 1982). A letter from the president-elect, vicepresident and the three candidates for presidentelect for the APA was circulated to members encouraging them to vote against revoking the declassification. The referendum ballots were returned by 9,644 members (37\%), with only 3,810 voting to revoke the decision. In a controversial discovery by Bieber (1987), the letter turned out to be developed and financed by the National Gay Task Force. This activist group allegedly solicited the signatures and purchased the membership list of 17,900 psychiatrists from the APA board of Trustee's (Bieber, 1987). The APA ethics committee investigated the matter after concerns that the circulated letter was not a true reflection of the opinions of the APA executive committee. ${ }^{8}$

\section{Current Implications for the Mental Health Professions}

\section{The medical legacy of homosexuality}

The historical lineage of medical and psychological diagnostic criteria retains considerable implications when applied to a clinical context to homosexuality today. Evidence of these remnants is found in the ongoing, albeit diminishing, presence of reparative therapies and other sexual orientation change efforts. ${ }^{9}$ Socarides

\footnotetext{
${ }^{8}$ The ethics committee decided that, although 'unwise', there had been no ethical breach of impropriety (Bieber, 1987). Bieber also suggests that there was an overrepresentation of younger voters which influenced the outcome, and that a compulsory vote should been instituted which he argues would have resulted in the referendum producing the opposite result.

${ }^{9}$ The prevalence of such therapies is difficult to quantify. By nature of their controversial practices, they do not widely advertise, however what is known is that their
}

(1973, 1992) suggested that appropriate therapy can only be based on accurate diagnosis. Since sexual orientation is no longer grounds for a medical diagnosis, we must question how and why SOCE and conversion therapies continue to exist. There is a legitimate concern that the mere existence of any conversion-type therapies can cause social harm. For example, portraying inaccurate views about the nature of sexual orientation (i.e., as a perversion), implying that sexuality may be a choice or preference rather than an innate orientation, and suggesting (even if it was empirically proven to be possible) that sexual orientation should be changed regardless of the individual's need or desire to change (i.e., ignoring the fact that homosexual or bisexual individuals may be happy with their orientation) are irresponsible and incorrect messages that should not be associated with science. The counterargument is that these therapies may sound reactionary and anti-gay, but that for those men and women who seek an alternative to the gay lifestyle, this could be a progressive treatment that should be available if there is a chance it works, and will realign the orientation of the patient with their desired preference (National Association for Research \& Therapy of Homosexuality [NARTH], 2010).

Spitzer (1984) makes an interesting suggestion: If there were an available and reliably effective 'treatment' for homosexuality, there would be a strong case for re-classifying it as a disorder. As the term presupposes, if there is a treatment for it, there must be a need to cure it; this in turn implies disorder. In an attempt to remain politically neutral on the topic he adds that he would make the same prediction regarding left-handedness, although the implications of homosexuality being categorised as clinically dysfunctional may be far more severe than for which hand you 'choose' to write with. The group 'Parents and Friends of Ex-Gays' (i.e., PFOX, supporting individuals who were, and are no longer, gay or lesbian) claims that homosexuality should still be classified as a mental disorder based on the distress it causes the individual; "In the history of psychiatry, no heterosexual has ever sought treatment for distress about his heterosexuality and wished to become homosexual" (Griggs, 2007) .

In 1997, the Council of Representatives of the APA affirmed its position that homosexuality is not a disorder and raised concerns about reparative therapies. In particular, the APA resolution raised the question of whether it is ethically possible for a psychologist to conduct conversion therapy with

prevalence is steadily reducing (Silver, 2014) with many larger clinics in the United States and Australia closing in the previous 12 months and with many clinics now only offering contact online. For a review, see Venn-Brown (2015) elsewhere in this special edition. 
individuals who are not capable of informed consent, including minors (APA, 1997).

\section{Professional Recommendations:}

A statement by the APA (2000) suggests that the role of the 'therapist should not involve determining the goal of any treatment, either coercively or through subtle influence'. It goes on to explicitly state that psychotherapeutic interventions claiming to convert or 'repair' homosexuality are 'based on theories with highly questionable scientific validity'. Furthermore, anecdotal claims of 'cures' are offset by reports of psychological harm. Although there are many published books by leading 'researchers' in this area, (e.g., Konrad, 1997; Macnutt, 2006; Nicolosi et al., 2009; Nicolosi \& Nicolosi, 2002), these leading reparative therapists are yet to produce any scientific research to substantiate or validate their claims of cure. This assertion is echoed by the APA (e.g., 2000, 2009) and APS (e.g., 2007).

Questionable case studies and anecdotal stories provide a pleasing form of face validity, but do not hold up to the empirical basis that psychology as a science should be built on.

The APS currently recommends that, until quantifiable research is produced, practitioners refrain from attempts to change the sexual orientation of their patients. It is also recommended by the APA that parents, guardians, and families of gay men and lesbian women avoid any form of treatment that portrays homosexuality as dysfunctional, a mental illness, or a developmental disorder. Although a homosexual or bisexual individual may experience conflict with their society, such conflict is not a symptom of dysfunction in the individual. Alternatives to treatment include seeking psychotherapies, psychoeducation services and social support services "that provide accurate information on sexual orientation and sexuality, increase family and school support and reduce rejection of sexual minority youth" (APS, 2007). Furthermore, the APS encourages academic research to determine the efficacy or otherwise of therapies or treatments that attempt to change a person's sexual orientation. ${ }^{10}$

\footnotetext{
${ }^{10}$ The reparative therapy literature actively stigmatises homosexuality, whilst conveniently ignoring the impact that such stigma would have in motivating people to want to 'cure' their homosexuality. This is confounded by the fact that it does all this under the guise of psychological expertise. The leader in this field, Joseph Nicolosi, has entitled his work "Handbook of therapy for unwanted homosexual attractions" although it is criticised by the APA for methodological reasons (APA, 2009). Also, it is worth mentioning that the reparative therapy literature neglects to refer to any potential risks to patients, or the strains this will place on their personal lives and interpersonal relationships.
}

\section{The task force evaluation}

\author{
In 2009, the Task Force on Appropriate
} Therapeutic Responses to Sexual Orientation conducted extensive research into conversion-style therapies. Although some individuals showed lessened physiological arousal to all sexual stimuli, there was not a single reported significant change to other-sex attractions that could be empirically validated. They found "serious methodological problems in this area of research, such that only a few studies met the minimal standards for evaluating whether... such efforts to change sexual orientation are effective" (APA, 2009, p.2). Other research also suggests that fundamentalist religious organisations often claim to have changed homosexuals to heterosexuals, but generally have not been documented in such a way as to permit their critical evaluation (Haldeman, 1991, 1994). Most claims about the 'success' of conversion therapies have appeared mainly in the mass media, rather than in scientific journals. Apart from the previously mentioned Spitzer (2001) study, there are two exceptions located using extensive search procedures (i.e., Byrd \& Nicolosi, 2002; Nicolosi et al., 2000), and both have received criticism of their credibility (Herek, 2010a).

\section{Conclusion}

It is evident through the course of this paper that the evolution of attitudes towards sexual orientation throughout the last century has been both rapid and extreme. This social category has seen its members move from clinically insane lawbreakers to liberated activists over the course of this time. Although the official position is that homosexuality has been delisted from both the DSM and the ICD (APA, 2000, 2009), we argue that this is merely a re-listing; in 1973, the term homosexuality was removed, however, in the current DSM and ICD-10, both have room to utilise non-heterosexuality for clinical diagnoses. As such, this removal is arguably a matter of reclassification. Regardless of whether the delisting is regarded as a removal or a reclassification, there seems to be remnants of unresolved conflicts within psychiatric circles.

Between the orthodox psychiatrists demanding referendums, and the progressive psychiatrists being involved in staging activist attacks at conventions, the entire debate became around diagnosis became theatrical debacle. A dispute fuelled by political controversy, much more so than by questions of science, raged between two opposing schools of psychological thought. The referendum outcome lacked objectivity, meaning the debate became a matter of subjective opinion. To avoid the extraneous factors (i.e., political and social influences) that became involved in this decision, an appropriate decision-making model could have been adhered to. For example, the 
decision could have acknowledged only clinical or scientifically based data that was relevant to the argument of homosexuality as a variation on sexual behaviour, and whether it fell within the realm of sexual normality. Nomenclature inclusion should be based in empirical evidence of a variation on sexual behaviour considered 'other than normal', otherwise it should be entirely removed with no room for subjective bias from a clinician.

It could be argued that any diagnostic criteria in the DSM that allows for a clinical classification, regardless of how subtle or ambiguous the classification might be, presumes that in some situations an appropriate intervention is to help the individual develop a heterosexual arousal pattern. Although this goes against the stances of both the APA and the APS, classifications such as in the current DSM ('sexual disorder not otherwise specified' for people who have symptomology revolving around 'distress about his or her sexual orientation') suggest an appropriate therapeutic activity is to help the individual concerned become more comfortable with his or her homosexual orientation, rather than attempting change. There appears to be an ethical issue with this incongruence; issues arise when people are led to believe orientation can be changed through intervention, and the same reparative therapies that are denounced by the APA can gain legitimacy purely through their existence, without room for 'loophole endorsements' through this classification issue.

For an extreme exemplar of the power this medical legacy still holds over attitudes towards sexuality, look no further than Uganda, which instigated the Anti-Homosexuality Bill of 2009. The bill originally called for seven years in prison for those caught attempting to commit homosexual acts, and death by hanging for same-sex behaviours for so-called 'serial offenders'. The bill was recently passed by the Parliament of Uganda on $20^{\text {th }}$ December 2013, although life in prison replaced the proposed death penalty punishment. The lingering clinical overtones are evident; attending the seminar to show support for the bill was Don Schmierer, a member serving on the board of Exodus International, a US reparative therapy group (Harris, Hinman, \&

Karamehmedovic, 2010). Even more significant is the fact that David Bahati, the Ugandan MP who introduced the bill, quoted psychological research as part of his justification for the bill, "Homosexual behaviour is learned. No scientific research has found provable biological or genetic differences between heterosexuals and homosexuals that were not caused by their behaviour" (Burraway, 2009; p. ??). This is clear evidence of the medical legacy left to homosexuality by the medical profession. Same-sex attracted citizens in Uganda are facing extreme punishment based on psychological research lacking in empirical grounding. Based on its medical legacy, clinical professions arguably need to take some of the blame for the lingering anti-gay attitudes in society; the clinical professions also have a responsibility to further the research in this arena until the matter is resolved.

\section{Research Profile}

Joel Anderson is completing a post-doctoral research fellowship at the University of Geneva in Switzerland. His primary research interest is in attempting to understand implicit biases (or nonconscious attitudes) towards various social groups, and in particular towards gay men and lesbian women. He has a particular interest in methods used for measuring non-conscious attitudes towards gay men and lesbian women, and he is now extending this research in his post-doctoral research, which aims to better understand how theories of biologically determined sexual orientation interact with both conscious and nonconscious attitudes towards gay people.

Elise Holland is a Postdoctoral Research Fellow in the Melbourne School of Psychological Sciences at the University of Melbourne, Australia. Her research broadly examines what it means to view and treat people as sexual objects. In particular, her work investigates the factors that facilitate sexual objectification, the perceptual and behavioural ramifications of objectifying others, and the effects of experiencing interpersonal objectification. Her most current research explores the sexual objectification of young girls, and the implications of objectifying girls on perceptions and behaviour.

\section{References}

Adam, B. (1987). The rise of a gay and lesbian movement. Boston, MA: Twayne Publishers.

American Psychiatric Association. (1952). Diagnostic and statistical manual: Mental disorders (Vol. 1). Washington, DC: Author.

American Psychiatric Association. (1968). Diagnostic and statistical manual: Mental disorders (Vol. 2). Washington, DC: Author.

American Psychiatric Association. (1980). Diagnostic and statistical manual: Mental disorders (Vol. 3). Washington, DC: Author.

American Psychiatric Association. (1987). Diagnostic and statistical manual: Mental disorders (Vol. 3-R). Washington, DC: Author.

American Psychiatric Association. (2000). COPP position statement on therapies focused on attempts to change sexual orientation (reparative or conversion therapies). Retrieved from http://www.psych.org/Departments/EDU/Librar y/APAOfficialDocumentsandRelated/PositionS tatements/200001a.aspx.

American Psychiatric Association (2009). 
[Resolution on Appropriate Affirmative Responses to Sexual Orientation Distress and Change Efforts.].

American Psychiatric Association. (2013). Diagnostic and statistical manual: Mental disorders (Vol. 5). Washington, DC: Author.

Armelli, J. A., Moose, E. L., Paulk, A., \& Phelan, J. E. (2012). A response to Spitzer's (2012) reassessment of his 2003 study of reparative therapy of homosexuality. Archives of Sexual Behavior, 1-2. doi:10.1007/s10508-012-0032-6

Australian Psychological Society. (2007). APS position statement on the use of therapies that attempt to change sexual orientation.

Barnes, D. M., \& Meyer, I. H. (2012). Religious affiliation, internalized homophobia, and mental health in lesbians, gay men, and bisexuals. American Journal of Orthopsychiatry, 82(4), 505-515. doi:10.1111/j.19390025.2012.01185.x

Bartoli, E., \& Gillem, A. R. (2008). Continuing to depolarize the debate on sexual orientation and religion: Identity and the therapeutic process. Professional Psychology: Research and Practice, 39(2), 202-209. doi:10.1037/07357028.39.2.202

Baunach, D. M. (2011). Decomposing trends in attitudes toward gay marriage, 1988-2006. Social Science Quarterly, 92(2), 346-363. doi:10.1111/j.1540-6237.2011.00772.x

Bayer, R. (1987). Homosexuality and American psychiatry - The politics of diagnosis. Princeton, NJ: Princeton University Press.

Bayer, R., \& Spitzer, R. L. (1982). Edited correspondence on the status of homosexuality in DSM-III. Journal of the History of the Behavioral Sciences, 18(1), 32-52. doi:10.1002/1520-6696(198201)18:1<32::aidjhbs $2300180105>3.0 . c 0 ; 2-0$

Bell, A. P., Weinberg, M. S., \& Hammersmith, S. K. (1981). Sexual preference: Its development in men and women (Vol. 2). Bloominton: Indiana University Press

Bieber, I. (1965). Clinical aspects of male homosexuality. Sexual inversion: The multiple roots of homosexuality, 248-267.

Bieber, I. (1987). On arriving at the American Psychiatric Association decision on homosexuality. Scientific controversies: Case studies in the resolution and closure of disputes in science and technology, 417-436.

Bostwick, W. B., Boyd, C. J., Hughes, T. L., West, B. T., \& McCabe, S. E. (2014). Discrimination and mental health among lesbian, gay, and bisexual adults in the United States. American Journal of Orthopsychiatry, 84(1), 35-45. doi:10.1037/h0098851

Bullough, V. L. (1976). Sexual variance in society and history. Oxford: John Wiley \& Sons.

Burraway, J. (2009, December 10). Uganda's
Official Media Centre Publishes Article Suggesting Anti-Homosexuality Act Not Needed [Online bulletin]. Retrieved from http://www.boxturtlebulletin.com/2009/12/10/1 7693.

Byrd, A., \& Nicolosi, J. B. (2002). A meta-analytic review of treatment of homosexuality. Psychological Reports, 90, 1139-1152.

Cochran, S. D., Mays, V. M., Alegria, M., Ortega, A. N., \& Takeuchi, D. (2007). Mental health and substance use disorders among Latino and Asian American lesbian, gay, and bisexual adults. Journal of Consulting and Clinical Psychology, 75, 785-794. doi: 10.1037/0022006X.75.5.785

Cooper, R. (2004). What is wrong with the DSM? History of Psychiatry, 15(1), 5-25. doi:10.1177/0957154x04039343

Crea, J. (2004, October 15). Conservative parent adjust to gay kids. Retrieved from http://www.washblade.com/print.cfm?content_i $\mathrm{d}=4038$.

Crisp, C. (2005). Homophobia and use of gay affirmative practice in a sample of social workers and psychologists. Journal of Gay \& Lesbian Social Services, 18(1), 51-70. doi:10.1300/J041v18n01_05

Drescher, J. (2003). An interview with Robert L. Spitzer, MD. In J. Drescher \& K. J. Zucker (Eds.), Ex-Gay Research: Analyzing the Spitzer Study and Its Relation to Science, Religion, Politics, and Culture (pp. 97-111). New York: the Hayworth Press.

Drescher, J., \& Zucker, K. J. (2013). Ex-gay research: Analyzing the Spitzer study and its relation to science, religion, politics, and culture. Binghampton, NY: Routledge.

Feinstein, B. A., Goldfried, M. R., \& Davila, J. (2012). The relationship between experiences of discrimination and mental health among lesbians and gay men: An examination of internalized homonegativity and rejection sensitivity as potential mechanisms. Journal of Consulting and Clinical Psychology, 80(5), 917. doi:10.1037/a0029425

Ford, C. S., \& Beach, F. A. (1951). Patterns of sexual behavior. New York: Harper and bros.

Fox, M. (2005, December 28). Charles W. Socarides, psychiatrist and psychoanalyst, is dead at 83 . New York Times.

Glassgold, J. M. (2008). Bridging the divide. Women \& Therapy, 31(1), 59-72. doi:10.1300/02703140802145227

Griggs, R. (March, 2007). Dear APA member [Newsletter archive]. Retrieved from http://pfox.org/Dear_APA_Member.html.

Haldeman, D. (1991). Sexual orientation conversion therapy for gay men and lesbians: A scientific examination. In J. Gonsiorek \& J. Weinrich (Eds.), Homosexuality: Research implications 
for public policy (Vol. 149-160, pp. 149-160).

Thousand Oaks, CA: Sage.

Haldeman, D. (1994). The practice and ethics of sexual orientation conversion therapy. Journal of Consulting and Clinical Psychology, 62(2), 221-227. doi:10.1037/0022-006x.62.2.221

Haldeman, D. (2004). When sexual and religious orientation collide: Considerations in working with conflicted same-sex attracted male clients. The Counseling Psychologist, 32(5), 691-715. doi:10.1177/0011000004267560

Harris, D., Hinman, K., \& Karamehmedovic, A. (2010, March, 10). Anti-Homosexual Bill In Uganda Causes Global Uproar. Nightline: Retrieved from http://abcnews.go.com/Nightline/antihomosexuality-bill-uganda-globaluproar/story?id=10045436\&page $=2$.

Herek, G. M. (2010a). Publication outlets used by the Cameron group [Blog]. Retrieved from http://psychology.ucdavis.edu/rainbow/html/fac ts_cameron_journals.html.

Herek, G. M. (2010b). Sexual orientation differences as deficits: Science and stigma in the history of American psychology. Perspectives on Psychological Science, 5, 693-699. doi:10.1177/1745691610388770

Herek, G. M., \& McLemore, K. A. (2013). Sexual prejudice. Annual Review of Psychology, 64, 309-333. doi:10.1146/annurev-psych-113011143826

Hooker, E. (1957). The adjustment of the male overt homosexual. Journal of projective techniques, 21(1), 18-31. doi:10.1080/08853126.1957.10380742

Hooker, E. (1958). Male homosexuality in the Rorschach. Journal of projective techniques, 22, 33-54. doi:10.1080/08853126.1958.10380822

Hooker, E. (1969). Parental relations and male homosexuality in patient and non-patient samples. Journal of Consulting and Clinical Psychology, 33, 140-142. doi: $10.1037 / \mathrm{h} 0027188$

Kinsey, A., Pomeroy, W., \& Martin, C. (1948). Sexual Behavior in the Human Male. Philadelphia, PA: W.B. Saunders.

Kinsey, A., Pomeroy, W., Martin, C., \& Gebhard, P. (1953). Sexual Behavior in the Human Female. Philadelphia: WB Saunders.

Konrad, J. (1997). You don't have to be gay: Hope and freedom for males struggling with homosexuality or for those who know of someone who is. Newport Beach, California: Pacific Publishing House.

Krajeski, J. (1996). Homosexuality and the mental health professions: A contemporary history. In R. P. Cabaj., \& T. S. Stein (Ed.), Textbook of homosexuality and mental health (pp. 17-31). Arlington, VA, US: American Psychiatric
Association.

Lenzer, J. (2003). Dr John Fryer (aka Dr H. Anonymous) obituary. British Medical Journal(326), 662.

Loftus, J. (2001). America's liberalization in attitudes toward homosexuality, 1973 to 1998 . American Sociological Review, 762-782. doi: $10.2307 / 3088957$

MacCannell, D., \& MacCannell, J. F. (1993). Violence, power and pleasure: A revisionist reading of Foucault from the victim perspective. In C. Ramazanoglu (Ed.), Up against Foucault: Explorations of some tensions between Foucault and Feminism (pp. 203-238). New York, NY: Routledge.

Macnutt, F. (2006). Can Homosexuality be healed? Grand Rapids, Michigan: Baker Publishing Group.

Marshal, M. P., Friedman, M. S., Stall, R., King, K. M., Miles, J., Gold, M. A., . . Morse, J. Q. (2008). Sexual orientation and adolescent substance use: a meta-analysis and methodological review. Addiction, 103(4), 546556. doi:10.1111/j.1360-0443.2008.02149.x

Mendelson, G. (2003). Homosexuality and Psychiatric Nosology. Australian and New Zealand Journal of Psychiatry, 37(6), 678-683. doi:10.1080/j.1440-1614.2003.01273.x

Meyer, I. H. (2003). Prejudice, social stress, and mental health in lesbian, gay, and bisexual populations: conceptual issues and research evidence. Psychological bulletin, 129, 674-697. doi:10.1037/0033-2909.129.5.674

National Association for Research and Therapy of Homosexuality. (NARTH, 2010). Female homosexual development [Newsletter archive] Retrieved from http://www.narth.com/docs/FemaleHomosexual Development.pdf.

Nicolosi, J. B., Byrd, A., Patton, M., Hallman, J., Carvalho, E., Rosebush, M., . . . Oram, K. (2009). Handbook of therapy for unwanted homosexual attractions: A guide to treatment. Grand Rapids, Michigan: Zondervan Publishing House.

Nicolosi, J. B., Byrd, A. D., \& Potts, R. W. (2000). Retrospective self-reports of changes in homosexual orientation: A consumer survey of conversion therapy clients. Psychological Reports, 86(3c), 1071-1088.

Nicolosi, J. B., \& Nicolosi, L. (2002). A parent's guide to preventing homosexuality. Downers Grove, Illinois: InterVarsity Press.

Oberstone, A. K., \& Sukoneck, H. (1976). Psychological adjustment and life style of single lesbians and single heterosexual women. Psychology of Women Quarterly, 1(2), 172188. doi:10.1111/j.1471-6402.1976.tb00817.x

Pew Research Centre. (2014). The global divide on homosexuality: Greater acceptance in more 
secular and affluent countries. Retrieved from http://www.pewglobal.org/2013/06/04/theglobal-divide-on-homosexuality/

Rensenberger, B. (1973, February 9). Psychiatrists Review Stand on Homosexuals; Statement to Be Drafted Term Misused. New York Times.

Robinson, B. (2010 February 16). Reparative therapy \& transformational ministries: An analysis of Dr. Spitzer's 2001 study about whether adults can change sexual orientation. Retrieved from http://www.religioustolerance.org/hom_spit.ht $\mathrm{m}$.

Rothblum, E. D., \& Factor, R. (2001). Lesbians and their sisters as a control group: Demographic and mental health factors. Psychological Science, 12(1), 63-69. doi:10.1111/14679280.00311

Scully, D. (2013). Understanding Sexual Violence: A Study of Convicted Rapists: A Study of Convicted Rapists. London: Routledge.

Siegelman, M. (1972). Adjustment of male homosexuals and heterosexuals. Archives of Sexual Behavior, 2(1), 9-25. doi:10.1007/BF01542016

Silver, M. (2014). The dangers of gay conversion therapy. The Sydney Morning Herald. Retrieved from http://www.smh.com.au/lifestyle/life/thedangers-of-gay-conversion-therapy-2014112411 soyy.html

Socarides, C. (1968). The overt homosexual. New York: Grune \& Stratton.

Socarides, C. (1973). Sexual perversion and the fear of engulfment. International Journal of Psychoanalytic Psychotherapy, 2(4), 432-448.

Socarides, C. (1978a). Homosexuality New York: Aronson.

Socarides, C. (1978b). The sexual deviations and the diagnostic manual. American Journal of Psychotherapy, 32(3). Retrieved from The Annals of Homosexuality website: http://www.narth.org/docs/annals.html Retrieved from http://www.narth.org/docs/annals.html

Socarides, C. (1992). Sexual politics and scientific logic: The issue of homosexuality. The Journal of Psychohistory, 19(3), 307-329.

Spector, M. (1977). Legitimizing homosexuality. Society, 14(5), 52-56. doi:10.1007/bf02700829

Spiegel, A. (2007, August 11). Interview by $N$. Mitchell [Radio Program]. 81 words: The inside story of psychiatry and homosexuality. All in the mind, : Australian Broadcasting Comission.

Spitzer, R. (1973). A proposal about homosexuality and the APA nomenclature: Homosexuality as an irregular form of sexual behavior and sexual orientation disturbance as a psychiatric disorder. American Journal of Psychiatry, 130, 12141216.
Spitzer, R. L. (1974). The Homosexual Decision-A Background Paper. Psychiatric News, 11-12.

Spitzer, R. L. (1981). The diagnostic status of homosexuality in DSM-III: A reformulation of the issues. American Journal of Psychiatry, 138(2), 210-215.

Spitzer, R. L. (2003). Can some gay men and lesbians change their sexual orientation? 200 participants reporting a change from homosexual to heterosexual orientation. Archives of Sexual Behavior, 32(5), 403-417. doi:10.1023/a:1025647527010

Spitzer, R. L. (2008). DSM-V: open and transparent? Psychiatric News, 43(14), 26-26.

Spitzer, R. L. (2012). Spitzer reassesses his 2003 study of reparative therapy of homosexuality. Archives of Sexual Behavior, 1-1. doi:10.1007/s10508-012-9966-y

Stengel, E. (1959). Classification of mental disorders. Bulletin of the World Health Organization, 21(4-5), 601-663. Retrieved from http://www.ncbi.nlm.nih.gov/pmc/articles/PMC 2537983/

Stoller, R., Marmor, J., Bieber, I., Gold, R., Socarides, C., Green, R., \& Spitzer, R. L. (1973). A symposium: Should homosexuality be in the APA nomenclature? American Journal of Psychiatry(11), 1207-1216.

Suppe, F. (1984). Classifying sexual disorders. Journal of homosexuality, 9(4), 9-28. doi:10.1300/J082v09n04_02

Thoits, P. A. (2013). Self, identity, stress, and mental health. In C. Aneshensel, J. Phelan, \& A. Bierman (Eds.), Handbook of the sociology of mental health (pp. 357-377). Amsterdam, Netherlands: Springer.

Whitman, J. S., Glosoff, H. L., Kocet, M. M., \& Tarvydas, V. (2006). Ethical issues related to conversion or reparative therapy. Retrieved from:

http://www.counseling.org/PressRoom/NewsRe leases.aspx?AGuid=b68aba97-2f08-40c2-a400$0630765 f 72 \mathrm{f} 4$

World Health Organisation. (1977). International Statistical Classification of Diseases and Related Health Problems (Vol. 9). Hyattsville, Maryland: Author.

World Health Organisation. (1990). International Statistical Classification of Diseases and Related Health Problems (Vol. 10). Hyattsville, Maryland: Author. 